\title{
PENGARUH MOTIVASI DAN INSENTIF TERHADAP PENILAIAN PRESTASI KERJA DOSEN TETAP DI UNIVERSITAS BUNDA MULIA
}

\author{
Yustinus Yuniarto \\ Email: yyuniarto@bundamulia.ac.id
}

\section{Penulis}

Yustinus Yuniarto adalah pengajar di Universitas Bunda Mulia dengan peminatan dalam bidang Manajemen Sumber Daya Manusia.

\begin{abstract}
Abstrak
This study will show the effect of incentives on job performance of tenured faculty at the Bunda Mulia University where the effect is not too large, while the motivation for job performance of tenured faculty at the Bunda Mulia University has considerable influence.
\end{abstract}

\section{Key Words}

Incentives, Motivation, Work Achievement

\section{PENDAHULUAN}

Di era globalisasi mutu pendidikan, perlu ditingkatkan melalui pengembangan kualitas institusi pendidikan. Salah satu upaya meningkatkan kualitas institusi pendidikan yaitu melalui peningkatan prestasi kerja dosen dalam melaksanakan proses belajar mengajar. Kualitas institusi pendidikan sangat dipengaruhi oleh masukan bagi sistim pendidikan diantaranya adalah mahasiswa, dosen dan fasilitas sarana pendukung proses belajar mengajar.

Faktor utama penyebab rendahnya mutu pendidikan adalah kondisi pengajar yaitu kualifikasinya tidak layak atau mengajar tidak sesuai bidang keahliannya. Tantangan yang terkait dengan mutu pendidik mencakup tantangan pribadi, kompetensional pribadi maupun ketrampilan pendidik dalam melaksanakan tugasnya. Kinerja dosen diukur 
berdasarkan beban kerja dosen mencakup kegiatan pokok yaitu merencanakan pembelajaran, melaksanakan proses bembelajaran, melakukan evaluasi pembelajaran, membimbing dan melatih, melakukan penelitian, melakukan pengabdian pada masyarakat dan melakukan tugas tambahan.

Kemampuan dosen mengajar merupakan dimensi paling utama untuk dilakukan monitoring. Penilaian ini dapat dilakukan oleh dosen sendiri, maupun oleh peserta didik melalui IMD (Indeks Mengajar Dosen) dalam melaksanakan pekerjaan. Faktor yang menentukan tingkat penilaian prestasi kerja seorang dosen, diantaranya adalah penilaian kinerja yang dilakukan oleh pihak pimpinan program studi dan mahasiswa.

Indeks Mengajar Dosen (IMD) yang ada di Universitas Bunda Mulia, dari tahun ajaran 2008/2009 sampai dengan tahun ajaran 2010/2011 mengalami kenaikan. Akan tetapi tidak semua program studi mengalami kenaikan. Hal ini dapat dilihat pada data. Dengan adanya kondisi tersebut, maka peneliti bermaksud untuk mengetahui apakah ada pengaruh kompensasi dan motivasi terhadap prestasi kerja.

\section{PERUMUSAN MASALAH}

Berdasarkan latar belakang di atas dapat diketahui bahwa kinerja dosen dalam proses belajar mengajar di Universitas Bunda Mulia belumlah optimal sehingga perumusan dalam penelitian ini adalah "Pengaruh motivasi dan insentif terhadap penilaian prestasi kerja dosen tetap di Universitas Bunda Mulia".

\section{TINJAUAN PUSTAKA}

\section{Motivasi}

Motivasi berasal dari motive atau dengan prakata bahasa latinnya, yaitu movere, yang berarti "mengerahkan". Hadari Nawawi dan M. Martini Hadari (2006, p92) motive atau dorongan adalah suatu dorongan yang menjadi pangkal seseorang melakukan sesuatu atau bekerja

Menurut Ernest J. McCormick yang dikutip oleh A.A Prabu Mangkunegara (2006, p94) menyatakan bahwa motivasi adalah kondisi yang berpengaruh 
membangkitkan, mengarahkan dan memelihara perilaku yang berhubungan dengan lingkungan kerja"

Motivasi menurut Edwin B. Flippo yang dikutip dari Hasibuan (2007, p143) yaitu“ Suatu keahlian, dalam mengarahkan pegawai dan organisasi agar mau bekerja secara berhasil, sehingga keinginan para pegawai dan tujuan organisasi sekaligus tercapai”

Dari beberapa pengertian diatas, dapat disimpulkan motivasi adalah keadaan dalam pribadi seseorang yang mendorong keinginan individu untuk melakukan kegiatankegiatan tertentu guna mencapai suatu tujuan.

Menurut Sukanto dan Handoko (1992, p271), faktor motivasional disebut juga faktor intrinsik yang meliputi kondisi intrinsik dan kepuasan pekerjaan. Serangkaian faktor ini meliputi: (a) pengakuan prestasi; (b) penghargaan; (c) pekerjaan itu sendiri; (d) tanggung jawab; dan (e) kemajuan.

\section{Insentif}

Metode insentif yang adil dan layak merupakan daya penggerak yang merangsang terciptanya pemeliharaan karyawan karena dengan pemberian insentif karyawan merasa mendapat perhatian dan pengakuan terhadap prestasi yang dicapainya sehingga semangat kerja dan sikap loyal karyawan akan lebih baik.

Pelaksanaan pemberian insentif dimaksudkan perusahaan terutama untuk meningkatkan prestasi kerja karyawan dan mempertahankan karyawan yang mempunyai produktivitas tinggi untuk tetap berada di dalam perusahaan.

Insentif itu sendiri merupakan rangsangan yang diberikan kepada karyawan dengan tujuan untuk mendorong karyawan dalam bertindak dn berbuat sesuatu untuk tujuan perusahaan. Hal ini berarti insentif merupakan suatu bentuk motivasi bagi karyawan agar dalam diri mereka timbul semangat yang lebih besar untuk berprestasi bagi perusahaan.

Ada beberapa definisi yang dikemukakan para ahli mengenai insentif seperti:

1. Menurut Sarwoto (1996, p144), Insentif merupakan sarana motivasi, dapat berupa perangsang atau pendorong yang diberikan dengan sengaja kepada para pekerja 
agar dalam diri mereka timbul semangat yang lebih besar untuk berprestasi bagi perusahaan.

2. Adapun definisi insentif menurut Hariandja (2002, p265) diartikan sebagai bentuk pembayaran langsung yang didasarkan atau dikaitkan langsung dengan kinerja dan gain sharing, yang juga dikaitkan dengan kinerja dan diartikan sebagai pembagian keuntungan bagi karyawan akibat peningkatan produktivitas atau penghematan biaya.

Berdasarkan uraian di atas maka dapat disimpulkan bahwa insentif merupakan salah satu bentuk rangsangan atau motivasi yang sengaja diberikan kepada karyawan untuk mendorong semangat kerja karyawan agar mereka bekerja lebih produktif lagi, meningkatkan prestasinya dalam mencapai tujuan perusahaan.

\section{Penilaian Prestasi Kerja}

Menurut Malayu S.P. Hasibuan (2000, p86) Penilaian prestasi kerja adalah evaluasi yang sistematis terhadap pekerjaan yang telah dilakukan oleh karyawan dan ditujukan untuk pengembangan.

Malayu S.P. Hasibuan (2002, p105) mendefinisikan prestasi kerja adalah suatu hasil kerja yang dicapai seseorang dalam melaksanakan tugas-tugas yang dibebankan kepadanya didasarkan atas kecakapan, pengalaman dan kesungguhan serta waktu.

Menurut Wirawan (2009, p11) Penilaian kinerja adalah proses penilai - pejabat yang melakukan penilaian - (appraiser) mengumpulkan informasi mengenai kinerja ternilai - pegawai yang dinilai - (appraise) yang didokumentasikan secara formal untuk meliai kinerja dengan membandingkannya dengan standar kinerjanya secaar periodik untuk membantu pengambilan keputusan manajemen SDM.

Mathis (2006, p382) menuliskan bahwa penilaian kinerja adalah proses mengevaluasi seberapa baik karyawan melakukan pekerjaan merea jika dibandingkan dengan seperangkat standar, dan kemudian mengomunikasikan informasi tersebut kepada karyawan. Penilaian kinerja juga disebut pemeringkatan karyawan, evaluasi karyawan, tinjauan karyawan, evaluasi kinerja, dan penilaian hasil. 
Kinerja karyawan menurut Gomes (1995) senantiasa berkaitan erat dengan dua faktor utama: a) kesediaan atau motivasi seseorang untuk bekerja yang menimbulkanusaha karyawan; b) kemampuan karyawan untuk melaksanakan pekerjaan.

Lebih lanjut Wirawan (2009, p24-26) menjelaskan fungsi dari evaluasi kinerja adalah sebagai berikut:

1. Memberikan balikan kepada pegawai ternilai mengenai kinerjanya.

2. Alat promosi dan demosi.

3. Alat memotivasi ternilai.

4. Sebagai alat pemutusan hubungan kerja dan merampingkan organisasi.

5. Menyediakan alasan hukum untuk pengambilan keputusan personalia.

6. Penentuan dan pengukuran tujuan kinerja.

7. Konseling kinerja buruk.

8. Mendukung rencana sumber daya manusia.

9. Menentukan kebutuhan pengembangan sumber daya manusia.

10. Merencanakan dan memvalidasi perekrutan tenaga baru.

11. Alat manajemen kinerja organisasi.

12. Pemberdayaan pegawai.

13. Menghukum anggota.

14. Penelitian.

Menurut Supardi (1989, p.69) indikator-indikator penilaian prestasi kerja adalah:

1. Kualitas kerja, Kualitas kerja ini meliputi akurasi, ketelitian, kerapian dalam melaksanakan tugas pekerjaan yang diberikan, mempergunakan dan memelihara alat-alat, memiliki ketrampilan dan kecakapan dalam bekerja.

2. Kuantitas kerja, meliputi keluaran atau output dan target kerja dalam kuantitas kerja.

3. Hubungan kerja, merupakan penilaian berdasar pada sikap dan kerjasama karyawan, terhadap pimpinan atau atasan, terhadap pihak perusahaan dan kesediaan dalam menerima perubahan kerja. 
4. Penyesuaian pekerjaan, merupakan penilaian prestasi kerja yang ditinjau dari kemampuan dalam melaksanakan tugasnya diluar pekerjaan maupun adanya tugas dalam kecepatannya berpikir dan bertindak dalam bekerja.

5. Ketangguhan merupakan pengukuran dari segi kernampuan orang dalam keandalan karyawan dalam melaksanakan tugas.

6. Keselamatan kerja, yaitu penilaian tentang bagaimana perhatian karyawan terhadap keselamatan kerjanya.

\section{METODOLOGI PENELITIAN}

\section{Populasi dan Sampel}

Dalam penelitan ini yang menjadi populasi adalah seluruh dosen tetap Universitas Bunda Mulia, Jakarta Utara sejumlah 65 orang. Sampel adalah sebagian dari jumlah dan karakteristik yang dimiliki oleh populasi tersebut. Sampel diambil berdasarkan random sampling (probability sampling), dengan teknik simple random sampling. Oleh karena populasi sudah diketahui jumlahnya, maka untuk menentukan jumlah sampel yang akan diteliti menggunakan rumus dari Sutrisno Hadi (1992, p220) :

$$
\begin{aligned}
& n=\frac{N}{N d^{2}+1} \\
& n=\frac{65}{65(0,1)^{2}+1} \\
& \mathrm{n}=39,39 \approx 39
\end{aligned}
$$

Jadi jumlah sampel dalam penelitian ini adalah 39 dosen tetap Universitas Bunda Mulia. 


\section{Metode Pengumpulan Data}

Terdapat dua cara untuk mengumpulkan data yang akan diperlukan untuk melakukan analisis dalam penelitian ini, yaitu sebagai berikut :

\section{Pengumpulan Data Primer}

Teknik pengumpulan data yang digunakan dalam penelitian ini adalah teknik pengumpulan data dengan menggunakan kuesioner. Kuesioner adalah teknik pengumpulan data yang dilakukan dengan cara memberi seperangkat pertanyaan atau pernyataan tertulis kepada responden untuk dijawab. Kuesioner merupakan teknik pengumpulan data yang efisien bila peneliti tahu dengan pasti variabel yang akan diukur dan tahu apa yang bisa diharapkan dari responden.

\section{Pengumpulan Data Sekunder}

Data sekunder diperoleh dari data yang diberikan oleh perusahaan, seperti struktur organisasi dan sejarah perusahaan. Skala yang digunakan dalam penelitian ini adalah skala Likert. Menurut Imam Ghozali ( 2005 ), skala Likert adalah skala yang berisi 5 tingkat preferensi

jawaban dengan pilihan sebagai berikut :

$1=$ Sangat tidak setuju

2 = Tidak setuju

$3=$ Ragu - ragu

$4=$ Setuju

$5=$ Sangat setuju 


\section{Metode Analisis}

Berdasarkan tujuan dari penelitian ini, maka beberapa metoda analisis data yang akan digunakan dalam penelitian ini adalah sebagai berikut :

\section{Uji Instrumen}

\section{Uji Validitas}

Uji validitas digunakan untuk mengukur sah atau valid tidaknya suatu kuesioner. Suatu kuesioner dikatakan valid jika pertanyaan pada kuesioner mampu untuk mengungkapkan sesuatu yang akan diukur oleh kuesioner tersebut menurut Imam Ghozali (2005). Untuk mengukur validitas dapat dilakukan dengan melakukan korelasi antar skor butir pertanyaan dengan total skor konstruk atau variabel. Sedangkan untuk mengetahui skor masing - masing item pertanyaan valid atau tidak, maka ditetapkan kriteria statistic sebagai berikut :

1. Jika $\mathrm{r}$ hitung > $\mathrm{r}$ tabel dan bernilai positif, maka variabel tersebut valid.

2. Jika $r$ hitung < r tabel, maka variabel tersebut tidak valid.

3. Jika $r$ hitung $>r$ tabel tetapi bertanda negatif, maka $\mathrm{H} 0$ akan tetap ditolak dan $\mathrm{H} 1$ diterima.

\section{Uji Reliabilitas}

Uji reliabilitas adalah alat untuk mengukur suatu kuisioner yang mempunyai indikator dari variabel atau konstruk. Suatu kuisioner dinyatakan reliabel atau handal jika jawaban seseorang terhadap pernyataan adalah konsisten atau stabil dari waktu ke waktu menurut Ghozali (2005). Pengukuran reliabilitas dapat dilakukan dengan dua cara yaitu :

1. Repeted measure atau pengukuran yaitu seseorang aka disodori pertanyaan yang sama pada waktu yang berbeda, dan kemudian dilihat apakah ia tetap konsisten dengan jawabannya

2. One shot atau pengukuran sekali saja dan kemudian hasilnya dibandingkan dengan pertanyaan yang lain atau mengukur korelasi antara jawaban dengan pertanyaan. 
Uji reliabilitas dapat dilakukan dengan menggunakan bantuan program SPSS, yang akan memberikan fasilitas untuk mengukur reliabilitas dengan uji statistik Cronbach Alpha ( $\alpha$ ). Suatu konstruk atau variabel dikatakan reliabel jika memberikan nilai Cronbanch Alpha > 0,60 menurut Ghozali (2005).

\section{Uji Model}

\section{Uji F}

Uji F digunakan pada dasarnya menunjukkan apakah semua variabel independen atau bebas yang dimasukkan dalam model mempunyai pengaruh secara bersama-sama terhadap variabel dependen atau terikat menurut Ghozali (2005). Langkah-langkah pengujiannya adalah sebagai berikut

1. Derajat kepercayaan $=5 \%$

2. Derajat kebebasan $\mathrm{f}$ tabel $(\alpha, \mathrm{k}, \mathrm{n}-\mathrm{k}-1)$

$$
\begin{aligned}
& \alpha=0,05 \\
& \mathrm{k}=\text { jumlah variabel bebas } \\
& \mathrm{n}=\text { jumlah sampel }
\end{aligned}
$$

3. Menentukan kriteria pengujian

$\mathrm{H} 0$ ditolak apabila $\mathrm{f}$ hitung $>\mathrm{f}$ tabel

HA ditolak apabila $\mathrm{f}$ hitung $<\mathrm{f}$ tabel

\section{Menentukan $\mathrm{f}$ dengan rumus}

$$
\mathrm{f}=\frac{\mathrm{R} 2 / \mathrm{k}}{(1-\mathrm{R} 2) /(\mathrm{n}-\mathrm{k}-1)}
$$

Dimana :

$$
\begin{aligned}
& \mathrm{R} 2 \text { = koefisien determinan berganda } \\
& \mathrm{n}=\text { jumlah sampel } \\
& \mathrm{k}=\text { jumlah variabel bebas }
\end{aligned}
$$

Kesimpulan :

Apabila $\mathrm{f}$ hitung < $\mathrm{f}$ tabel maka $\mathrm{H} 0$ diterima dan HA ditolak, artinya tidak ada pengaruh secara simultan. 
Apabila $\mathrm{f}$ hitung > f tabel maka $\mathrm{H} 0$ ditolak dan HA diterima, artinya ada pengaruh secara simultan.

\section{Analisis Regresi Linier}

Analisis regresi linier digunakan untuk mengetahui ada tidaknya pengaruh antara kompensasi terhadap motivasi dan implikasinya terhadap kinerja. Dalam regresi linier berganda terdapat 3 variabel, yaitu :

a. Variabel Bebas ( X1), yaitu Insentif

b. Variabel Bebas ( X2 ), yaitu Motivasi

c. Variabel Terikat ( Y ), yaitu Penilaian Prestasi Kerja

Untuk menguji variabel tersebut maka digunakan analisa regresi linier berganda dengan rumus sebagai berikut :

$$
\begin{gathered}
\mathrm{Y} 1=\mathrm{b} 1 \mathrm{X} 1+\mathrm{e} 1 \\
\mathrm{Y} 2=\mathrm{b} 1 \mathrm{X} 1+\mathrm{b} 2 \mathrm{X} 2+\mathrm{e} 2
\end{gathered}
$$

Dimana :

$\mathrm{Y}=$ Kinerja karyawan

b1, b2 = Koefisien garis regresi

$\mathrm{X} 1=$ Insentif

$\mathrm{X} 2$ = Motivasi

$\mathrm{e}=$ Residual atau prediction error

\section{Uji t}

Uji t pada dasarnya menunjukkan seberapa jauh pengaruh satu variabel penjelas atau independen secara individual dalam menerangkan variasi variabel dependen. Langkah - langkah pengujiannya adalah sebagai berikut :

1. Menentukan formasi H0 dan H1

H0 : bi = 0 ,berarti variabel independen bukan merupakan variabel penjelas yang signifikan terhadap variabel dependen.

HA : bi $\neq 0$, berarti variabel tersebut merupakan penjelas yang signifikan 
terhadap variabel dependen.

2. Level of significant

Sampel 100 orang, maka $\mathrm{t}$ tabel $=\mathrm{t}(\alpha=0,05)$

3. Menentukan kriteria pengujian

H0 gagal ditolak apabila t hitung < t tabel

H1 ditolak apabila t hitung $>\mathrm{t}$ tabel

4. Tes Statistik

$\mathrm{t}=$ rata-rata sampel pertama - rata-rata sampel kedua standar error perbedaan rata-rata kedua sampel

Kesimpulan :

Apabila $t$ hitung > $t$ tabel maka $\mathrm{H} 0$ ditolak, artinya ada pengaruh positif.

Apabila $t$ hitung $<\mathrm{t}$ tabel maka $\mathrm{H} 0$ diterima, artinya tidak ada pengaruh.

\section{HASIL DAN ANALISIS DATA}

\section{Analisis Data dan Interpretasi}

Analisis data dilakukan secara statistik induktif dengan menggunakan aplikasi program SPSS versi 17 khususnya analisis regresi untuk mengetahui pengaruh motivasi dan insentif terhadap prestasi kerja dosen tetap di Universitas Bunda Mulia, Jakarta Utara.

Pengujian validitas digunakan untuk mengukur valid dan tidak valid suatu pernyataan kuesioner yang disebarkan ke responden, maka kuesioner dinyatakan valid jika pernyataan kuesioner mampu menangkap sesuatu yang akan diukur oleh kuesioner tersebut. Sedangkan pengujian reliabilitas merupakan metode untuk mengukur suatu jawaban pernyataan. Suatu kuesioner dinyatakan reliabel jika jawaban terhadap pernyataan adalah konsisten.

Pengujian validitas dan reliabilitas sekaligus digunakan untuk memastikan bahwa instrumen penelitian pada masing-masing variabel yaitu Insentif (X1), dan Motivasi (X2) sebagai variabel independent dan Prestasi Kerja sebagai variabel dependent memiliki nilai kesahihan dan dapat dipercaya sebagai alat pengumpulan data primer. 


\begin{tabular}{|l|r|r|r|r|r|}
\hline & & & \multicolumn{1}{|c|}{ Model Summary $^{\mathrm{b}}$} \\
Model & $\mathrm{R}$ & $\mathrm{R}$ Square & \multicolumn{1}{c|}{$\begin{array}{c}\text { Square } \mathrm{R} \\
\text { Square }\end{array}$} & $\begin{array}{c}\text { Std. Error of the } \\
\text { Estimate }\end{array}$ & Durbin-Watson \\
\hline 1 & $.415^{\mathrm{a}}$ & .173 & .127 & .79909 & 1.852 \\
\hline
\end{tabular}

a. Predictors: (Constant), Motivasi, Insentif

b. Dependent Variable: Peneilaian PrestasiKerja

Dari tabel diatas diperoleh nilai DW sebesar 1,852. Nilai ini mendekati angka 2 maka dapat disimpulkan tidak terdapat autokorelasi positif atau negatif yang artinya tidak terjadi autokorelasi. Berdasarkan penghitungan autokorelasi diatas, tampak bahwa diantara variabel bebas dan terikat tidak terdapat autokorelasi, artinya model analisis regresi yang akan dilakukan peneliti dapat dilakukan dengan baik.

\begin{tabular}{|ll|r|r|r|r|r|}
\hline \multicolumn{1}{|l|}{ ANOVA $^{\mathbf{b}}$} \\
\hline 1 & Sum of Squares & \multicolumn{1}{c|}{$\mathrm{df}$} & Mean Square & F & \multicolumn{1}{c|}{ Sig. } \\
\hline & Regression & 4.795 & 2 & 2.397 & 3.754 & $.033^{\mathrm{a}}$ \\
& Residual & 22.988 & 36 & .639 & & \\
& Total & 27.782 & 38 & & & \\
\hline
\end{tabular}

a. Predictors: (Constant), Motivasi, Insentif

b. Dependent Variable: Peneilaian PrestasiKerja

Langkah 1 : Merumuskan Hipotesis

Ho2 : Tidak terdapat pengaruh insentif dan motivasi terhadap penilaian prestasi kerja secara simultan.

Ha2 : Terdapat pengaruh insentif dan motivasi terhadap penilaian prestasi kerja secara simultan.

Langkah 2 : Signifikasi $=0,033$

Pengujian menggunakan $\alpha=0,05$

Langkah 3 : Ho ditolak karena signifikansi lebih kecil dibandingkan $\alpha$ yaitu sig 0,033

dibandingkan dengan alpha 0,05.

Langkah 4 : Kesimpulan 
Ha diterima yaitu terdapat pengaruh insentif dan motivasi terhadap penilaian prestasi kerja secara simultan.

Berdasarkan hasil simultan dengan menggunakan anova diketahui bahwa secara bersama-sama variabel bebas, yaitu insentif dan motivasi memiliki pengaruh yang nyata terhadap penilaian prestasi kerja.

\begin{tabular}{|c|c|c|c|c|c|c|c|c|}
\hline \multicolumn{9}{|c|}{ Coefficients $^{a}$} \\
\hline \multirow{2}{*}{\multicolumn{2}{|c|}{ Model }} & \multicolumn{2}{|c|}{ Unstandardized Coefficients } & \multirow{2}{*}{$\begin{array}{c}\text { Standardized } \\
\text { Coefficients } \\
\text { Beta }\end{array}$} & \multirow[b]{2}{*}{$\mathrm{t}$} & \multirow[b]{2}{*}{ Sig. } & \multicolumn{2}{|c|}{ Collinearity Statistics } \\
\hline & & B & Std. Error & & & & Tolerance & VIF \\
\hline \multirow[t]{3}{*}{1} & (Constant) & .628 & 1.226 & & .513 & .611 & & \\
\hline & Kompensasi & -.254 & .235 & -.173 & -1.083 & .286 & .901 & 1.109 \\
\hline & Motivasi & .780 & .286 & .436 & 2.730 & .010 & .901 & 1.109 \\
\hline
\end{tabular}

a. Dependent Variable: Penilaian PrestasiKerja

Persamaan regresi yang dihasilkan adalah

Keterangan :

$$
\mathrm{Y}=\mathbf{0 , 6 2 8}-\mathbf{0 , 2 5 4} \mathrm{X} 1+\mathbf{0 , 7 8 0} \mathrm{X} 2
$$

$\mathrm{Y}=$ Penilaian Prestasi kerja

$\mathrm{X} 1=$ Insentif

$\mathrm{X} 2$ = Motivasi

Artinya konstanta sebesar 0,628 menyatakan bahwa jika variabel insentif dan motivasi sebesar 0 maka penilaian prestasi kerja 0,628.

Koefisien regresi sebesar -0,254 menyatakan bahwa jika insentif berubah sebesar 1 satuan dari variabel motivasi maka penilaian prestasi kerja akan turun sebesar -0,254.

Koefisien regresi sebesar 0,780 menyatakan bahwa jika motivasi berubah sebesar 1 satuan dari variabel insentif maka penilaian prestasi kerja akan turun sebesar 0,780. 


\section{Normal P-P Plot of Regression Standardized Residual}

\section{Dependent Variable: PrestasiKerja}

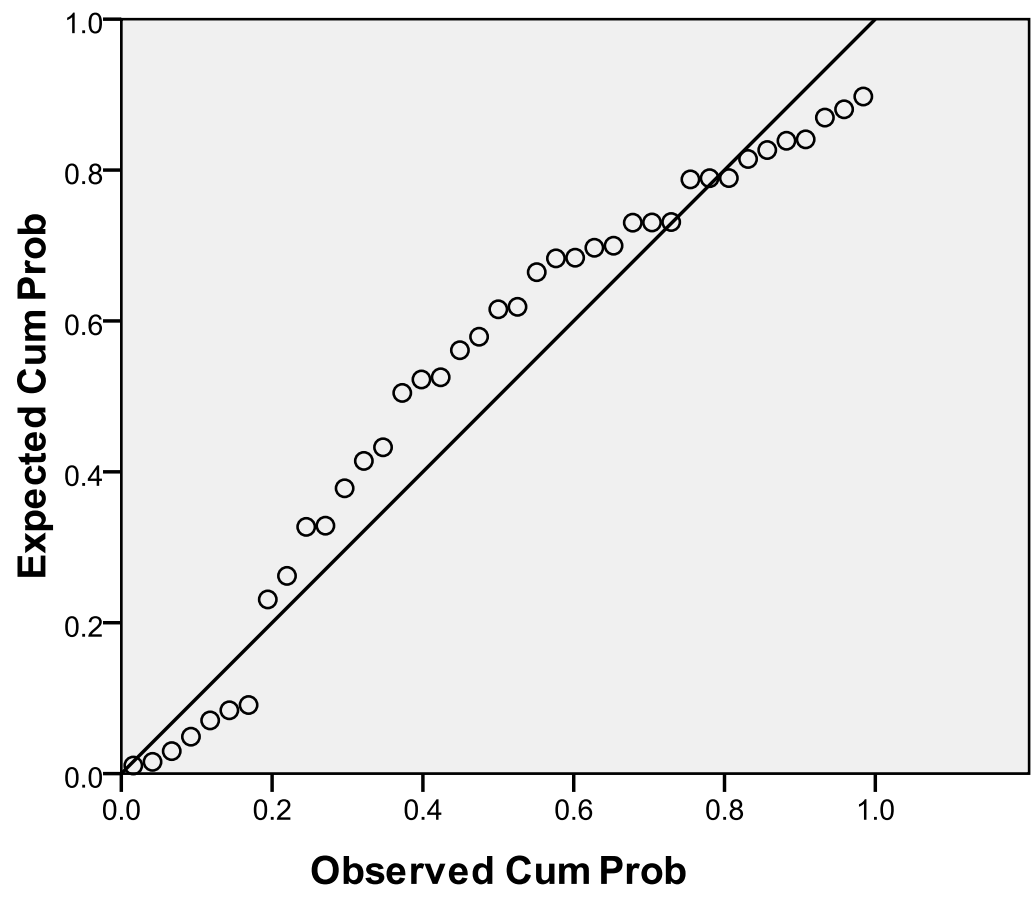

Dari gambar diatas dapat disimpulkan bahwa data dari penelitian ini adalah normal, dapat dilihat dari titik-titik atau data yang menyebar mengikuti garis diagonal sehingga dapat dikatakan bahwa model regresi layak dipakai karena memenuhi asumsi normalitas. 


\section{Scatterplot}

\section{Dependent Variable: PrestasiKerja}

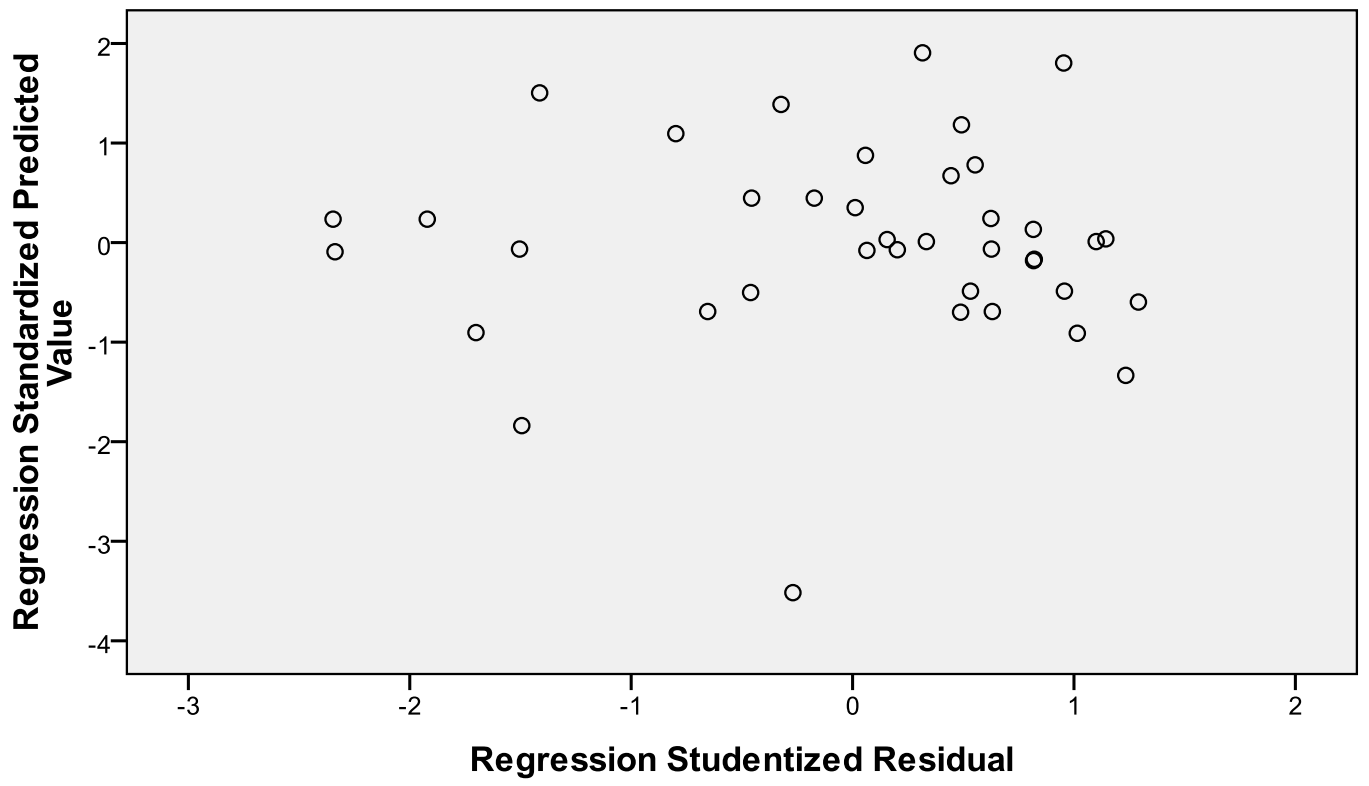

Dari hasil pengolahan data dapat dilihat titik-titik menyebar secara acak serta tersebar yang tidak membentuk suatu pola. Hal ini berarti tidak terjadi heterokedastisitas pada model regresi dan dapat disimpulkan bahwa dalam model regresi tidak terjadi ketidaksamaan varians dari residual satu pengamatan ke pengamatan lainnya.

\section{KESIMPULAN DAN SARAN}

Dari penelitian di atas, maka penulis mengambil simpulan:

1. Pada insentif terhadap prestasi kerja dosen tetap di Universitas Bunda Mulia, Jakarta Utara, tidak berpengaruh terlalu besar, sebesar $(-0,254)$.

2. Pada motivasi terhadap prestasi kerja dosen tetap di Universitas Bunda Mulia, Jakarta Utara, ada pengaruh sebesar $(0,780)$. 
3. Dapat dilihat dan diketahuinya seberapa besar pengaruh insentif dan motivasi terhadap prestasi kerja dosen tetap di Universitas Bunda Mulia, Jakarta Utara, dengan hasil regresi berganda $Y=0,628-0,254 X 1+0,780 X 2$.

\section{Saran}

Adapun beberapa saran tersebut sbb :

1. insentif tetap dipertahankan, walaupun insentif yang telah ada saat ini kurang atau tidak berpengaruh terhadap prestasi kerja.

2. Perlu adanya motivasi terhadap dosen khususnya dosen tetap di UBM, dimana motivasi tersebut berupa lebih ditingkatkannya lagi pemenuhan fasilitas dalam kegiatan belajar mengajar, serta kenyamanan lingkungan kerja dan dukungan kerja dari sesama dosen maupun ketua program studi.

\section{DAFTAR PUSTAKA}

Hariandja, Marihot Tua Efendi. (2002), Manajemen Suumber Daya Manusia: Pengadaan, Pengembangan, Pengkompensasian, dan Peningkatan Produktivitas Pegawai, Grasindo, Jakarta.

Hasibuan, Malayu. (2000), Manajemen Sumber Daya Manusia, Bumi Aksara, Jakarta Notoatmodjo, Soekidjo. (2003), Pengembangan Sumber Daya Manusia, Rineka Cipta, Jakarta

Sastrodiningrat, Soebagio. (2002), Kapita Selekta Manajemen \& Kepemimpinan, IND-HILL-CO, Jakarta.

Sugiyono. (1999), Metode Penelitian Bisnis, Alfabeta, Bandung.

Siagian, Sondang. (2004), Teori Motivasi dan Aplikasinya, Rineka Cipta, Jakarta. 

di Universitas Bunda Mulia

Umar, Husein. (2010), Desain Penelitian MSDM dan Perilaku Karyawan, Rajawali Pers, Jakarta. 